\title{
Heterobranch sea slugs (Mollusca: Gastropoda) from Ascension Island, South Atlantic Ocean
}

\author{
VINICIUS PADULA ${ }^{1}$, PETER WIRTZ ${ }^{2}$ AND MICHAEL SCHRÖDL ${ }^{1}$ \\ ${ }^{1}$ SNSB-Zoologische Staatssammlung München, Münchhausenstrasse 21, 81247, München, Germany and Department Biology II \\ and GeoBio-Centre, Ludwig-Maximilians-Universität München, Germany, ${ }^{2}$ Centro de Ciências do Mar, Universidade do Algarve, \\ P-80oo-117, Faro, Portugal
}

\begin{abstract}
The small volcanic island of Ascension is situated in the middle of the South Atlantic Ocean, more than $1500 \mathrm{~km}$ from the coast of Africa, its nearest continental area. To date, eight 'opisthobranch' species were reported from the island. As a result of a recent survey, 10 species were found. Seven species are new records from Ascension: Platydoris angustipes (Mörch, 1863), Diaulula sp., Dolabrifera dolabrifera (Rang, 1828), Aplysia parvula Guilding in Mörch, 1863 and Caliphylla mediterranea A. Costa, 1867, and two new species: Phidiana mimica sp. nov.; and Felimida atlantica sp. nov. Half of the species found have a wide geographical distribution, being not restricted to the Atlantic Ocean. However, traditional taxonomy based on few characters is probably masking complexes of species.
\end{abstract}

Keywords: Nudibranchia, opisthobranchs, Phidiana, Felimida, isolation, teratology

Submitted 5 November 2013; accepted 23 March 2014; first published online 16 May 2014

\section{INTRDDUCTION}

Ascension is a small volcanic island situated in the middle of the South Atlantic Ocean. Its nearest land areas are more than $1000 \mathrm{~km}$ away (St Helena Island: $1130 \mathrm{~km}$; Liberia, West Africa: $1536 \mathrm{~km}$; Fernando de Noronha archipelago: $2048 \mathrm{~km}$ ). The approximately triangular island is only $97 \mathrm{~km}^{2}$, being surrounded mostly by rocky shores and small sandy beaches. For a description of general characteristics of the coast of Ascension see Price \& John (1980). As pointed out by these authors, in the beginning of the 2oth Century many expeditions used Ascension as a stop-off point during their journeys. However, few observations were made about the marine life of the island. Improvement on the knowledge came later, with publication of annotated lists of species, in particular those by Rosewater (1975) for marine molluscs, Manning \& Chace Jr (1990) for decapod and stomatopod crustaceans and Lubbock (1980) for shore fish.

Rosewater's (1975) list of molluscs included data previously reported by other authors, such as Packer (1968) and mostly Smith (1890a, b), and the information provided by the examination of collections made by Mrs Hutchfield and by R.B. Manning. Rosewater (1975) also considered valid the presence of some species on the island based only on verbal communications by Mrs Hutchfield, that is, without the existence of specimens for examination (e.g. Cypraea tigris Linnaeus, 1758 and Tonna galea Linnaeus, 1758). His list covered 89 species, eight of them under the 'Opisthobranchia' (Rosewater, 1975: p. 24), including one pyramidellid. The list also included two

Corresponding author:

V. Padula

Email: viniciuspadula@yahoo.com species of Siphonariidae. In the past, the family Pyramidellidae was considered part of Opisthobranchia by some authors (e.g. Boettger, 1955) but later included among the group of basal, not well-resolved heterobranchs (Haszprunar, 1985). It is now clear that Opisthobranchia per $s e$ is not a natural group (Jörger et al., 2010; Kocot et al., 2013, among others), and a recent reclassification of traditional groups such as Acteonoidea, Nudibranchia and Sacoglossa has been presented by Wägele et al. (2014).

Among the eight opisthobranch species reported from Ascension by Rosewater (1975), most are shelled forms, including two deep water species collected by 'The Challenger' (see Table 1). No representatives of other diverse groups, such as Nudibranchia or Sacoglossa, were known from the island until now. Based on material collected in a recent expedition by the Shallow Marine Surveys Group (SMSG) and the South Atlantic Environmental Research Institute (SAERI), we here update the information on the heterobranch sea slugs of Ascension Island, including the description of two new species.

\section{MATERIALS AND METHDDS}

Material was collected manually from tide pools and through SCUBA diving down to a depth of $15 \mathrm{~m}$, in AugustSeptember 2012. Specimens were photographed alive, preserved in $96 \%$ ethanol and deposited in the malacological collection of the Zoologische Staatssammlung München (ZSM), Germany. Taxonomic identifications were based mostly on external characters, such as body morphology and colour pattern, in comparison to field guides and checklists (Cervera et al., 2004; Valdés et al., 2006), and original descriptions. At least two species presented an external morphology and colour pattern previously unknown for any described species. Specimens of 
Table 1. Heterobranch sea slugs from Ascension. New records marked* (Eupulmonata not included).

\begin{tabular}{|c|c|c|}
\hline Taxon & Record from Ascension & Geographical distribution \\
\hline \multicolumn{3}{|l|}{ "LOWER HETEROBRANCHIA" } \\
\hline \multicolumn{3}{|l|}{ ACTEONOIDEA } \\
\hline Micromelo undatus (Bruguière, 1792) & $\begin{array}{l}\text { Rosewater (1975: p. 24); present study (ZSM } \\
\quad \text { Mol 20130108) }\end{array}$ & Circumglobal \\
\hline \multicolumn{3}{|l|}{ NUDIPLEURA } \\
\hline \multicolumn{3}{|l|}{ PLEUROBRANCHOIDEA } \\
\hline Pleurobranchus areolatus Mörch, 1863 & $\begin{array}{l}\text { Rosewater (1975: p. 25); present study (ZSM } \\
\quad \text { Mol 20130103, 20130104, 20130113) }\end{array}$ & $\begin{array}{l}\text { Tropical eastern Pacific, western and eastern } \\
\text { Atlantic; Ascension }\end{array}$ \\
\hline \multicolumn{3}{|l|}{ NUDIBRANCHIA } \\
\hline * Platydoris angustipes (Mörch, 1863) & Present study (ZSM Mol 20130105) & Florida to south-eastern Brazil; Ascension* \\
\hline * Diaulula sp. & Present study (ZSM Mol 20130107) & Ascension* \\
\hline * Felimida atlantica sp. nov. & Present study (ZSM Mol 20130114) & Ascension* \\
\hline * Phidiana mimica sp. nov. & $\begin{array}{l}\text { Present study (ZSM Mol } 20130109, \\
\text { 20130110) }\end{array}$ & Ascension* \\
\hline \multicolumn{3}{|l|}{ EUOPISTHOBRANCHIA } \\
\hline \multicolumn{3}{|l|}{ UMBRACULOIDEA } \\
\hline Umbraculum umbraculum (Lightfoot, 1786) & $\begin{array}{l}\text { Rosewater (1975: p. 25, as U. mediterraneum); } \\
\text { present study }\end{array}$ & Circumglobal \\
\hline \multicolumn{3}{|l|}{ CEPHALASPIDEA } \\
\hline Cylichna cylindracea (Pennant, 1777) & Smith (189ob) & $\begin{array}{l}\text { Eastern Atlantic, Mediterranean Sea, Cape } \\
\text { Verde, Canary Islands, Ascension (deep } \\
\text { water), St Helena, Tristan da Cunha. }\end{array}$ \\
\hline Cylichna orycta (Watson, 1883) & Smith (189ob) & Ascension (deep water) \\
\hline Haminoea hydatis (Linnaeus, 1758) & Smith (1890a, b); Rosewater (1975: p. 25) & $\begin{array}{l}\text { Northeastern Atlantic, Azores, } \\
\text { Mediterranean Sea, Ascension and } \\
\text { St Helena }\end{array}$ \\
\hline \multicolumn{3}{|l|}{ ANASPIDEA } \\
\hline Aplysia dactylomela Rang, 1828 & Rosewater (1975: p. 25) & Atlantic and Mediterranean \\
\hline * Aplysia parvula Guilding in Mörch, 1863 & Present study (ZSM Mol 20130115) & Circumglobal \\
\hline * Dolabrifera dolabrifera (Rang, 1828) & $\begin{array}{l}\text { Present study (ZSM Mol 20130106, } \\
\text { 20130112) }\end{array}$ & Circumglobal \\
\hline \multicolumn{3}{|l|}{ PANPULMONATA } \\
\hline \multicolumn{3}{|l|}{ SACOGLOSSA } \\
\hline * Caliphylla mediterranea A. Costa, 1867 & Present study (ZSM Mol 20130111) & $\begin{array}{l}\text { Mediterranean Sea, Senegal, Caribbean Sea, } \\
\text { Brazil, Ascension* }\end{array}$ \\
\hline \multicolumn{3}{|l|}{ SIPHONARIOIDEA } \\
\hline Siphonaria alternata (Say, 1826) & Rosewater (1975: p. 24 , as S. picta) & $\begin{array}{l}\text { Bermuda, Florida, Caribbean Sea, Brazil, } \\
\text { Ascension (?) }\end{array}$ \\
\hline Williamia gussoni (Costa O. G., 1829) & Smith (1890a, b); Rosewater (1975: p. 24) & $\begin{array}{l}\text { Azores, Cape Verde, Mediterranea Sea, } \\
\text { St Helena and Ascension }\end{array}$ \\
\hline \multicolumn{3}{|l|}{ PYRAMIDELLOIDEA } \\
\hline Pyramidella dolabrata (Linnaeus, 1758) & Rosewater (1957: p. 24) & Circumtropical \\
\hline
\end{tabular}

these species were dissected under a stereomicroscope. The buccal bulb was manually cleaned and immersed in a solution of $10 \%$ sodium hydroxide $(\mathrm{NaOH})$ to dissolve soft tissues. Cleaned jaws and radula were transferred to distilled water and mounted for photography in the scanning electronic microscope LEO 1430 VP, at the ZSM. For the study of the reproductive system, it was first cleaned and isolated from adjacent systems and then drawn with the aid of a camera lucida.

\section{RESULTS}

During the expedition, ten species were collected: Micromelo undatus (Bruguière, 1792); Pleurobranchus areolatus Mörch, 1863; Platydoris angustipes (Mörch, 1863); Diaulula sp.; Felimida atlantica sp. nov.; Phidiana mimica sp. nov.; Umbraculum umbraculum (Lightfoot, 1786); Dolabrifera dolabrifera (Rang, 1828); Aplysia parvula Guilding in Mörch, 1863; and Caliphylla mediterranea A. Costa, 1867. Seven species represent new records for Ascension Island (see species remarks below), among them two new nudibranch species, representing the first record of this group from the island.

\section{SYSTEMATICS}

Class GASTROPODA Cuvier, 1795

HETEROBRANCHIA Gray, 1840

ACTEONOIDEA d'Orbigny, 1843

Family APLUSTRIDAE Gray, 1847

Genus Micromelo Pilsbry, 1895

Micromelo undatus (Bruguière, 1792)

(Figure 1A)

MATERIAL EXAMINED

One specimen, $6 \mathrm{~mm}$ long (preserved) (crawling on a rock in $5 \mathrm{~m}$ depth, English Bay, Ascension Island) (ZSM Mol 20130108), P. Wirtz coll., 10 September 2012.

\section{REMARKS}

Micromelo undatus is considered a circumtropical species (Valdés et al., 2006), but this needs to be tested through 

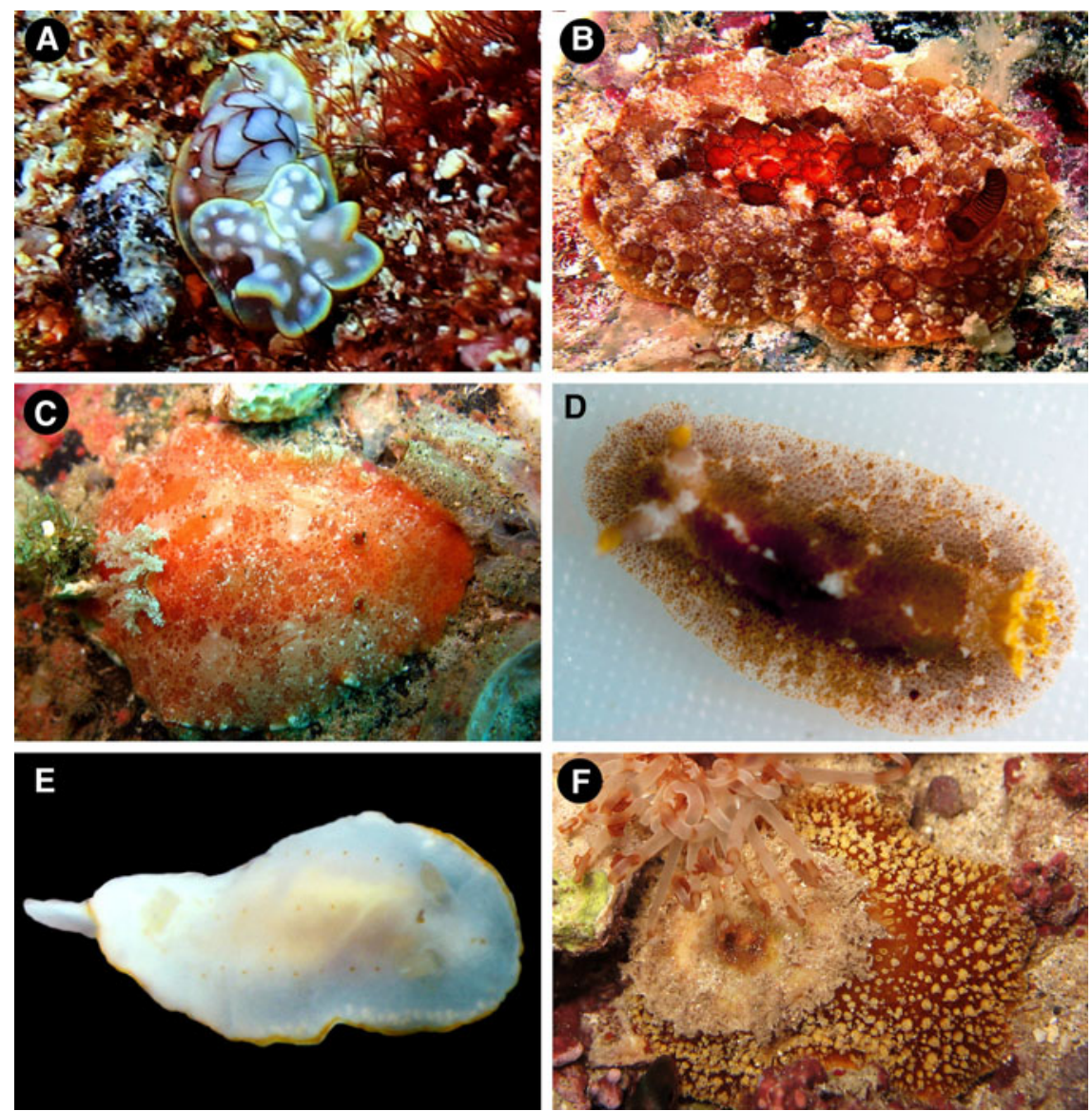

Fig. 1. Heterobranch sea slugs from Ascension Island: (A) Micromelo undatus (Bruguière, 1792) (ZSM Mol 20130107); (B) Pleurobranchus areolatus Mörch, 1863 (ZSM Mol 20130104); (C) Platydoris angustipes (Mörch, 1863) (ZSM Mol 20130105); (D) Diaulula sp. (ZSM Mol 20130107, photograph by Simon Morley); (E) Felimida atlantica sp. nov. (holotype, ZSM Mol 20130114); (F) Umbraculum umbraculum (Lightfoot, 1786) (not collected).

comparative morphological and molecular studies. It was first recorded from Ascension by Rosewater (1975) based on four specimens, one of them collected alive.

EUTHYNEURA Spengel, 1881 NUDIPLEURA Wägele \& Willan, 2000 PLEUROBRANCHOIDEA Gray, 1827 Family PLEUROBRANCHIDAE Gray, 1827 Genus Pleurobranchus Cuvier, 1804 Pleurobranchus areolatus Mörch, 1863

(Figure $1 \mathrm{~B}$ )

\section{MATERIAL EXAMINED}

Three specimens, $30 \mathrm{~mm}$ long preserved (ZSM Mol 20130103), $32 \mathrm{~mm}$ long preserved (ZSM Mol 20130104) and $25 \mathrm{~mm}$ long preserved (ZSM Mol 20130113) (found under rocks between 5 and $10 \mathrm{~m}$ depth, English Bay and Soudan Bay), coll. P. Wirtz, August-September 2012.

\section{REMARKS}

Originally described from St Thomas, in the Caribbean Sea (Mörch, 1863), P. areolatus was later recorded from many localities in the tropical western Atlantic (see Valdés et al., 2006), and also in the eastern Pacific and eastern Atlantic (Cervera et al., 2004; Camacho-García et al., 2005). The first record of this species from Ascension was provided by Rosewater (1975) based on a single specimen. It is not clear if the differences in body colour pattern and dorsal papillae reported for $P$. areolatus may, in fact, be indicative that more than one species is involved (Rudman, 2000). Ascension specimens present the most common reddish pattern known for the species, being very similar to the specimens from Brazil, illustrated by García et al. (2002: Figure 2H) and Padula et al. (2012, Figure 5D).

\section{NUDIBRANCHIA Cuvier, 1817}

EUCTENIDIACEA Tardy, 1970

Family DISCODORIDIDAE Bergh, 1891

Genus Platydoris Bergh, 1877

Platydoris angustipes (Mörch, 1863)

(Figure ${ }_{1} \mathrm{C}$ )

\section{MATERIAL EXAMINED}

Two specimens, 35 and $42 \mathrm{~mm}$ long preserved (under a rock in $10 \mathrm{~m}$ depth, English Bay) (ZSM Mol 20130105), coll. P. Wirtz, 6 September 2012.

\section{REMARKS}

Widespread in the tropical western Atlantic, with many records along the Caribbean to south-eastern Brazil (Valdés et al., 2006; Padula et al., 2012), P. angustipes is herein for the first time recorded from Ascension Island, representing the easternmost known record for the species. 
Genus Diaulula Bergh, 1878

Diaulula sp.

(Figure 1D)

MATERIAL EXAMINED

One specimen, $22 \mathrm{~mm}$ long preserved (under a rock in $10 \mathrm{~m}$ depth, North East Bay) (ZSM Mol 20130107), coll. S. Morley, 31 August 2012.

\section{REMARKS}

Due to the high number of similar morphotypes or species, the family Discodorididae represents one of the most puzzling groups in the Atlantic Ocean (Camacho-García et al., 2014). This morphotype from Ascension resembles Diaulula hummelincki (Ev. Marcus \& Er. Marcus, 1963) in the colour of the rhinophores and gill, and young specimens of Discodoris branneri MacFarland, 1909 in general colour and external morphology (Alvim \& Pimenta, 2013). The specific identity of this material can only be clarified after further comparative morphological and molecular studies.

Family CHROMODORIDIDAE Bergh, 1891 Genus Felimida Ev. Marcus, 1971 Felimida atlantica sp. nov.

(Figures $1 \mathrm{E}, 2,6 \mathrm{~A}$ )
TYPE MATERIAL

Holotype: $12 \mathrm{~mm}$ long, preserved. Dissected, radula and jaws mounted on stub for SEM, reproductive system studied (English Bay, water depth: $15 \mathrm{~m}$, under a large rock) (ZSM Mol 20130114), coll. P. Wirtz, 9 September 2012.

\section{EXTERNAL MORPHOLOGY}

Body long, oval in shape, flattened. Mantle smooth, with a series of densely arranged, small, irregular granular glands (mantle dermal formations, 'MDFs') along its border, except on the anterior margin. Foot relatively straight, posterior region projected and pointed. Oral tentacles short and conical. Rhinophoral sheath low, base of rhinophores smooth, distal portion with 15 adjacent lamellae. Gill relatively short, with five unipinnate leaves.

\section{BODY COLOUR}

Body predominantly white or translucent white. Dorsal mantle with three longitudinal series of small orange dots, running from each rhinophore and from the midpoint between them in the direction of the gill. Mantle edge bordered by a thin yellowish orange band. Rhinophores and gill whitish, pale cream (Figure $1 \mathrm{E}$ ). Ventral mantle and foot white.
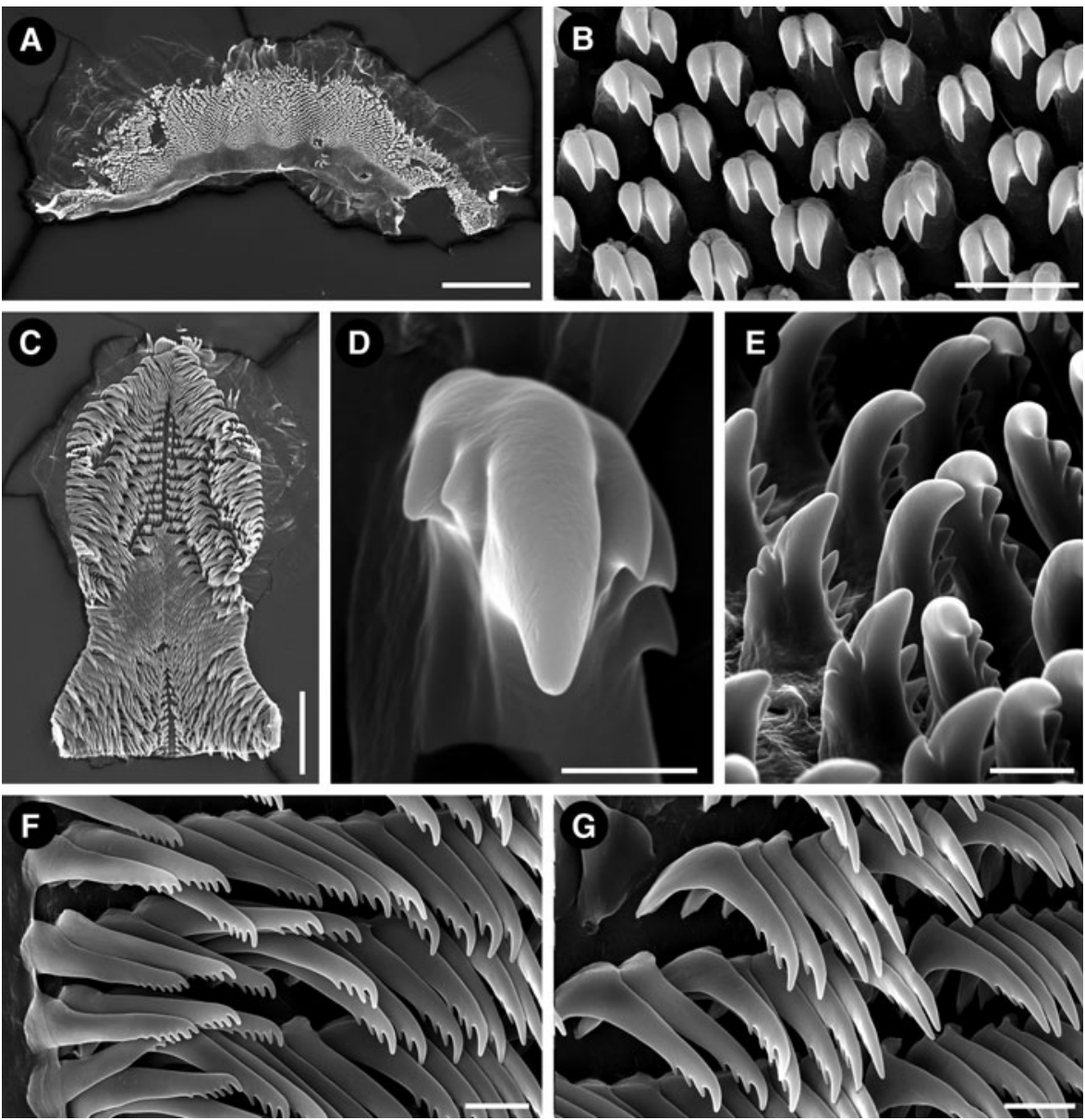

Fig. 2. Felimida atlantica sp. nov. (holotype, ZSM 20130114), SEM micrographs. Labial cuticle: (A) opened labial cuticle; (B) elements of the labial cuticle. Radula: (C) entire radula; (D) detail of the first lateral tooth; (E) first lateral teeth, ventral view; (F) outermost lateral teeth; (G) mid-lateral teeth. Scale bars: A, $200 \mu \mathrm{m}$; B, $10 \mu \mathrm{m}$; C, $200 \mu \mathrm{m}$; D, $5 \mu \mathrm{m}$; E, $10 \mu \mathrm{m}$; F, G, $20 \mu \mathrm{m}$ 


\section{LABIAL CUTICLE AND RADULA}

Oral tube initially narrow, widening posteriorly in the junction with the labial cuticle; when open, labial cuticle is irregular, semi-oval in shape (Figure $2 \mathrm{~A}$ ). Labial cuticle covered by many small, mostly bicuspid elements. In some elements, each cusp may be subdivided, presenting a total of three or four cusps (Figure 2B). Radula wider in its posterior portion; posterior end straight (Figure $2 \mathrm{C}$ ). Radular formula $42 \times 26.0 .26$ in the $12 \mathrm{~mm}$ fixed holotype (ZSM Mol 20130114). First lateral tooth with a large base and a prominent central cusp; up to three external short and triangular cusps disposed in series; one or two short internal cusps near central one. Lateral teeth thin and elongated, with a series of apical, small, rounded cusps; four in the first laterals and six in the most external ones. Outermost lateral teeth straighter than lateral ones, with a shorter base and up to seven apical, small, rounded cusps (Figures $2 \mathrm{D}-\mathrm{G}$ ).

\section{REPRODUCTIVE SYSTEM}

Hermaphroditic, triaulic, anterior portion occupying a relatively small space between the buccal mass and digestive gland. Hermaphrodite duct wide, flattened and short; ampulla moderately long, thin, situated above the female gland. Prostate elongated, with many folds; distal deferent duct wide and folded, disposed laterally and ventrally to seminal receptacle; transition between deferent duct and penis well demarcated; male and female atrium in a common space. Vagina very thin and long, projected below to the seminal receptacle; seminal receptacle cylindrical, $1 / 2$ of bursa size, inserting ventrally in the vagina region through a small and curved region; bursa copulatrix rounded. Uterine duct long, thin, resembling vagina, projecting ventrally from bursa copulatrix in direction to the gonopore, inserting female gland mass near to oviduct. Oviduct short. Female glands well developed, nidamental region with a rounded portion, ventrally to vagina (Figure 6A).

\section{ETYMOLOGY}

The specific name refers to the Atlantic Ocean.

\section{GEOGRAPHIC DISTRIBUTION}

Only known from its type locality: English Bay, Ascension Island, South Atlantic Ocean.

\section{REMARKS}

Due to the body form, smooth mantle, the arrangement of MDFs, pectinate radular teeth and the arrangement of the reproductive system, the single specimen studied is allocated in the genus Felimida. According to Johnson \& Gosliner's hypothesis (2012) Felimida comprises Atlantic species previously attributed to the genera Chromodoris and Glossodoris. Felimida atlantica sp. nov. resembles four other Atlantic and Mediterranean Felimida species: Felimida grahami (Thompson, 1980) and Felimida paulomarcioi (Domínguez, García \& Troncoso, 2006) from the Caribbean Sea and Brazil, respectively, Felimida kpone (Edmunds, 1981) from Ghana, and Felimida purpurea (Risso in Guérin, 1831), from the Mediterranean and the eastern Atlantic. All these species share the general whitish dorsal mantle, with or without orange/pink spots or lines, with a marginal yellowish orange line, and purple/reddish pigment in the rhinophores and branchial leaves (Edmunds, 1981; Debelius \& Kuiter,
2008). Also, F. purpurea and F. paulomarcioi share a very similar reproductive system (García-Gomez, 2002; Domínguez et al., 2006), while the reproductive system of F. grahami and F. kpone were not described up to date. These species are differentiated by details in coloration and radular morphology. Felimida atlantica sp. nov differs from all by having white rhinophores and gill. This is an important feature because the colour of these structures does not present wide variation in Felimida species. Differences in the radular morphology are more difficult to state because the general pattern in Felimida is very similar. Few specimens of each Felimida species were anatomically studied and potential intraspecific variation, including ontogenetic, is not well known. However, the innermost lateral teeth seem to carry some specific information. Innermost lateral teeth of Felimida atlantica sp. nov. have one, mostly two, internal and only three external cusps (Figure 2D, E). This agrees with the variation reported for F. purpurea, two internal, three-four external cusps (García-Gomez, 2002), but these species differ in the colour of the rhinophores and the gill and also in the dorsal colouration, F. purpurea not presenting the small orange dots found in F. atlantica sp. nov. The dorsal pattern of $F$. atlantica sp. nov. agrees with the description of F. grahami, F. paulomarcioi and F. kpone, with orange/ reddish spots disposed in longitudinal lines. In fact, it is not clear if $F$. paulomarcioi does not simply represent a variation of F. grahami, as commented by Padula et al. (2011). Felimida atlantica sp. nov. differs from these and other known Felimida species by the diagnostic white rhinophores and gill, combined with the reduced number of cusps in the innermost lateral teeth.

\section{DEXIARCHIA Schrödl, Wägele \& Willan, 2001 Family FACELINIDAE Bergh, 1889 Genus Phidiana Ev. Marcus, 1971 Phidiana mimica sp. nov. (Figures 3A, B, 4, 5, 6B)}

\section{TYPE MATERIAL}

Holotype: $4 \mathrm{~mm}$ long preserved. Dissected, radula and jaws mounted on stub for SEM, reproductive system not studied (English Bay, water depth: 10-15 m, under a rock) (ZSM Mol 20130110), coll. P. Wirtz, 9 September 2012.

Paratype: $7 \mathrm{~mm}$ long preserved. Dissected, radula and jaws mounted on stub for SEM, reproductive system studied (English Bay, water depth: 10-15 m, under a rock) (ZSM Mol 20130109), coll. P. Wirtz, 9 September 2012.

\section{EXTERNAL MORPHOLOGY}

Body long and narrow, distinct and elongated head with long and pointed oral tentacles; rhinophores comparatively short and smooth. Foot with the same width as the body, except the anterior portion that is wider. Anterior region of the foot curved with thin lateral projections; posterior end short and pointed. Cylindrical and elongated cerata distributed in groups; anterior group forming a short arch, posterior groups in lines; each group with 8-15 cerata. Anus situated at the base of the anterior cerata of the second ceratal cluster, on the right side of the body. Genital aperture situated laterally on the right side of the body below the first group of cerata. The position of the renal pore could not be determined. 

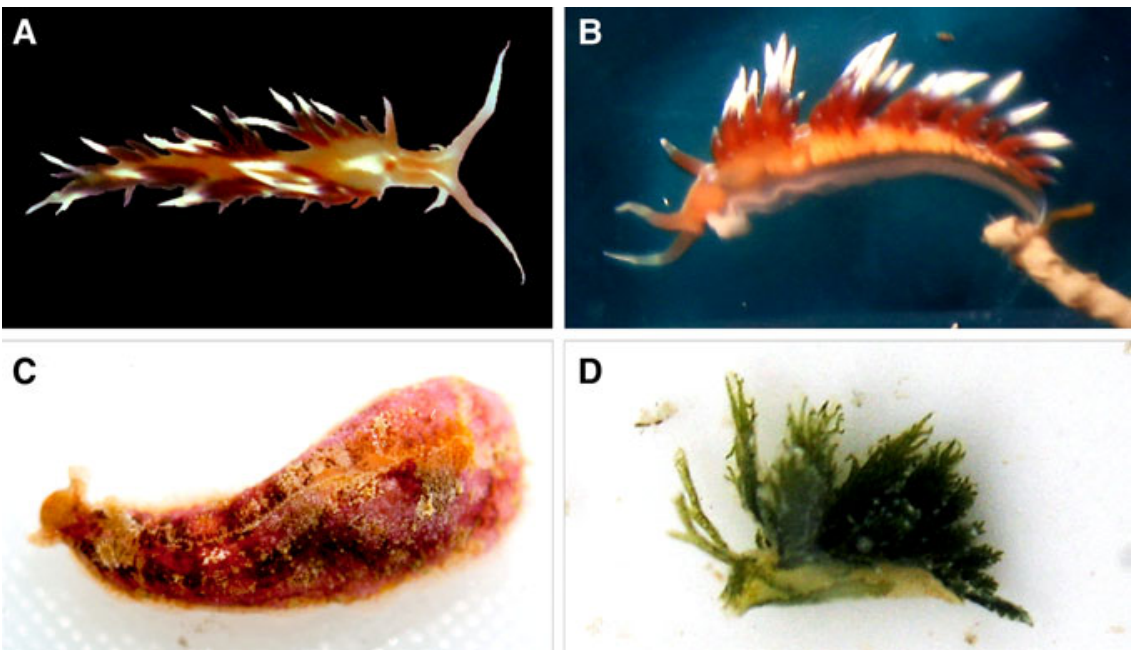

D

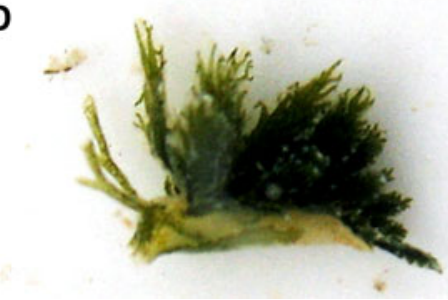

Fig. 3. Heterobranch sea slugs from Ascension Island: (A) Phidiana mimica sp. nov., dorsal view (holotype, ZSM Mol 20130109); (B) Phidiana mimica sp. nov., lateral view (holotype, ZSM Mol 20130109); (C) Dolabrifera dolabrifera (Rang, 1828) (ZSM Mol 20130112, photograph by Simon Morley); (D) Caliphylla mediterranea A. Costa, 1867 (ZSM 20130111).

\section{BODY COLOUR}

Body orange; dorsally, from the base of each oral tentacle a thin dorsal white line runs in direction to the region between the rhinopores. Dorsal region above the pericardium with a triangular white spot. Dorsal region posterior to the pericardium orange. Foot corners translucent white. Oral tentacles with orange-reddish bases, central region fade yellowish and distal portion white. Rhinophores reddish with white tips. Cerata deep red in their lower half, with a short bluish zone in transition to the white distal portion (Figure $3 \mathrm{~A}, \mathrm{~B}$ ). It seems that the deep red colour of the cerata is derived from the content of the digestive gland, but it could not be confirmed through the photographs or examining the preserved material. The bluish zone and the distal white portion are pigments on the surface of the cerata.

JAWS AND RADULA

Uniseriate radula with 17 (holotype ZSM Mol 20130110) and 19 teeth (paratype ZSM Mol 20130109); radular teeth with a prominent and smooth central cusp (Figure $4 \mathrm{D}$ ) and five or six lateral smooth denticles (Figure ${ }_{4} \mathrm{E}$ ). The paratype is a teratological specimen with asymmetrical teeth. Some teeth present one side with few $(3-6)$ large denticles and the other with up to 20 small denticles or even smooth (Figure $5 \mathrm{~B}$ ).
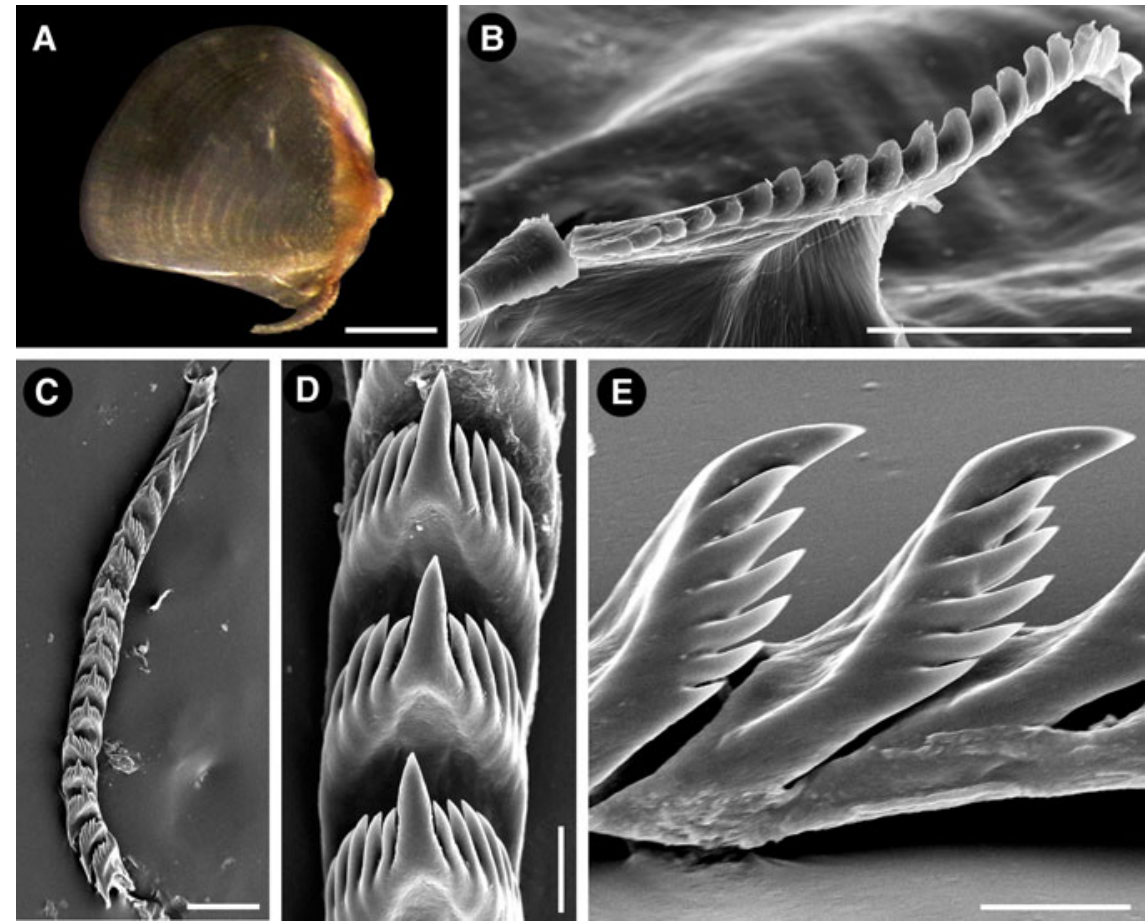

Fig. 4. Phidiana mimica sp. nov.: (A) left jaw (photograph on stereo microscope) (paratype, ZSM 20130109). SEM micrographs: (B) border of the jaw (paratype, ZSM 20130109); (C) entire radula (holotype, ZSM 20130110); (D) radular teeth (holotype, ZSM 20130110); (E) detail of radular teeth (holotype, ZSM 20130110). Scale bars: A, $250 \mu \mathrm{m} ; \mathrm{B}, \mathrm{C} 100 \mu \mathrm{m} ; \mathrm{D}, \mathrm{E}, 20 \mu \mathrm{m}$. 

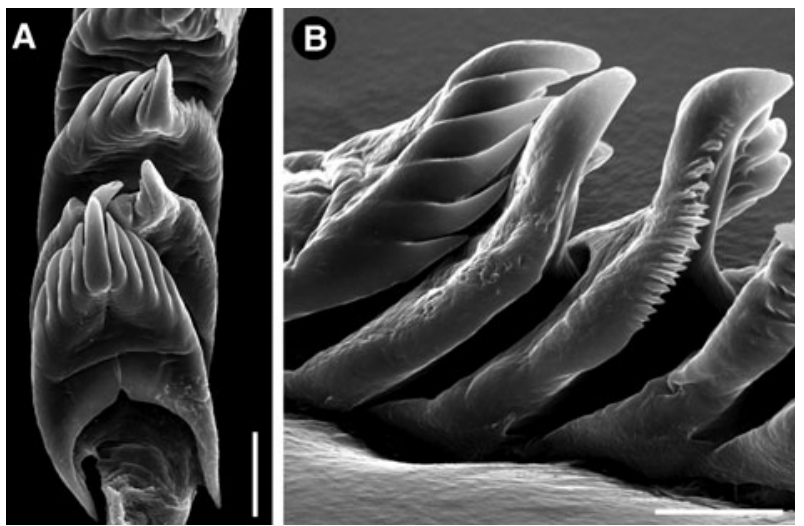

Fig. 5. Phidiana mimica sp. nov., teratological radula of the paratype (ZSM 20130109): (A) radular teeth, dorsal view; (B) lateral view of radular teeth showing teratology. Scale bars: A, $25 \mu \mathrm{m} ; \mathrm{B}, 20 \mu \mathrm{m}$.

Holotype and paratype with thin and relatively high jaws (Figure 4A). Masticatory border of the jaws long, projected and denticulate, with a single row of large and spaced, spoonlike teeth (Figure $4 \mathrm{~A}, \mathrm{~B}$ ).

\section{REPRODUCTIVE SYSTEM}

Hermaphroditic, androdiaulic. Proximal gonoduct thin and long. Ampulla elongated, wide, with a turn on its proximal region. Distal portion of ampulla narrowing, postampullary gonoduct short, dividing into deferent duct and oviduct. A differentiate prostate not present. Deferent duct very short, thin, connected to a curved, muscular, penis. A small projection is present in the superior portion of the penis, appearing as a small protuberance above the gonopore (Figure 6B). Vagina elongated, moderately wide, connecting to the female gland mass, oviduct and the stalk of receptaculum seminis; the latter with irregular shape and surface, having a distinct yellowish colour.

\section{ETYMOLOGY}

From the Latin mimicus (and the Greek mimikos) due to the similarity in external appearance of the new species to Phidiana lynceus Bergh, 1867.
GEOGRAPHICAL DISTRIBUTION

Only known from its type locality: English Bay, Ascension Island, South Atlantic Ocean.

\section{REMARKS}

At first glance, based on general body morphology and colour, the studied specimens could erroneously be identified as belonging to Phidiana lynceus, a common tropical western Atlantic species, recorded also from the Canary Islands and Ghana (Edmunds, 1975; Cervera et al., 2004). However, there are differences in the shape of the rhinophores, being lamellated in P. lynceus and smooth in P. mimica sp. nov., and in the colour of some regions of the body, such as the rhinophores and dorsal region, posterior to the head. The rhinophores of $P$. lynceus have transparent bases, the central region orange or red and a yellowish distal portion (Valdés et al., 2006: p. 257), while they are reddish with white tips in $P$. mimica sp. nov. A central longitudinal white line runs along the entire dorsal region in $P$. lynceus, while in $P$. mimica sp. nov. it is absent. The jaws and the radula of the two species are also different: the jaws of $P$. lynceus are proportionally longer than the jaws of $P$. mimica sp. nov.; $P$. lynceus has 6-9 denticles on each side of the prominent central cusp of the radular teeth (Bergh, 1867; Padula, 2007), while the central cusp is smooth in the teeth of $P$. mimica sp. nov.

Another species that resembles P. mimica sp. nov. is Phidiana indica (Bergh, 1896) from the tropical Indo-Pacific but also recorded in the Mediterranean as an exotic species (Zenetos et al., 2003). However, the general body colour pattern is different, $P$. indica presenting blue and yellow areas on the oral tentacles and cerata which are absent in $P$. mimica sp. nov.

As pointed recently in a broad molecular phylogenetic study in aeolids (Carmona et al., 2013: figure 1), the traditional generic placements in the family Facelinidae seem to not reflect the natural history of the group and apparently need a general revision. We tentatively allocated the new species in the genus Phidiana based on characteristics of external morphology, jaw, radula and reproductive system (Rudman, 1980, 1999). An exception is the smooth rhinophores, as most Phidiana species have perfoliated rhinopores, but $P$. indica, for example, does not. This species formerly was
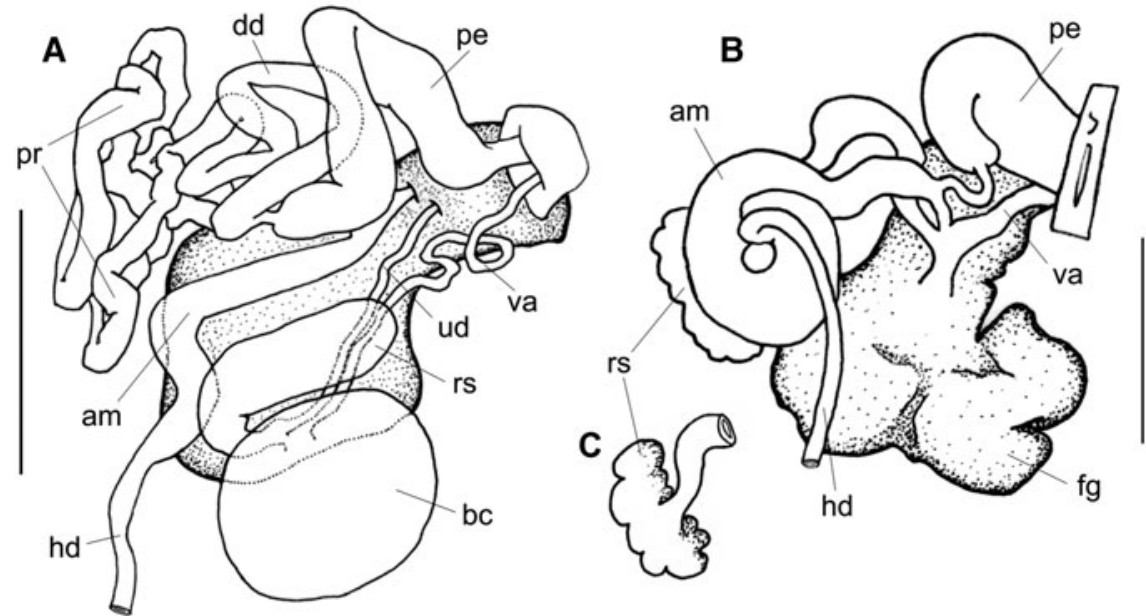

Fig. 6. Reproductive system, dorsal view: (A) Felimida atlantica sp. nov. (holotype, ZSM 20130114); (B) Phidiana mimica sp. nov. (holotype, ZSM 20130109). Scale bars: A, $1 \mathrm{~mm}$; B, o.5 mm. am, ampulla; bc, bursa copulatrix; dd, deferent duct; fg, female gland; hd, hermaphrodite duct; pe, penis; pr, prostate; rs, receptaculum seminis; ud, uterine duct; va, vagina. 
placed into the genera Learchis, Caloria, Hervia and Facelina by different authors (see Rudman, 1999).

One unusual feature of the paratype of $P$. mimica sp. nov. is the asymmetrical morphology of the radular teeth, with a single tooth presenting different shapes on each side of the central cusp, and adjacent teeth presenting different morphology (Figure $5 \mathrm{~B}$ ). It probably represents an abnormality, indeed illustrates how the systematics of aeolid nudibranchs can be even more complicated. Only new comprehensive studies may clarify the boundaries within the Facelinidae subgroups.

TECTIPLEURA Schrödl et al., 2011

EUOPISTHOBRANCHIA Jörger et al., 2010

UMBRACULOIDEA Dall, 1889 (1827)

Family UMBRACULIDAE Dall, 1889

Genus Umbraculum Schumacher, 1817

Umbraculum umbraculum (Lightfoot, 1786)

(Figure $1 \mathrm{~F}$ )

\section{MATERIAL EXAMINED}

One specimen photographed alive, material not collected.

\section{REMARKS}

Another species considered to have a wide geographical distribution in the Atlantic, Indo-Pacific and also eastern Pacific waters (Uribe et al., 2013). Many names were synonymized to Umbraculum umbraculum, and at least some may represent valid names of more restricted distributed, cryptic, species. This species was first recorded from Ascension under the name Umbraculum mediterraneum (Lamarck, 1819) based on a single shell (Rosewater, 1975: p. 26). During the recent survey, a living specimen was photographed (Figure $1 \mathrm{~F}$ ) and several more were observed by the second author, confirming the occurrence of the species in the island.

ANASPIDEA Fischer, 1883

Family APLYSIIDAE Lamarck, 1809

Genus Dolabrifera Gray, 1847

Dolabrifera dolabrifera (Rang, 1828)

(Figure ${ }_{3} \mathrm{C}$ )

\section{MATERIAL EXAMINED}

Two specimens, 6 and $10 \mathrm{~mm}$ long, preserved (under rocks in $12 \mathrm{~m}$ depth in Northeast Bay) (ZSM Mol 20130112), collector not recorded, 6 September 2012. One specimen, $13 \mathrm{~mm}$ long, preserved (under rocks on $10 \mathrm{~m}$ depth, English Bay) (ZSM Mol 20130106), collector not recorded, 6 September 2012.

\section{REMARKS}

This species is distributed circumglobally in tropical and subtropical waters (Rudman, 2003). However, as commented for Micromelo undatus and Umbraculum umbraculum, this wide distribution should be investigated with more detailed, comparative morphological and molecular studies. This is the first record of $D$. dolabrifera from Ascension Island.

Genus Aplysia Linnaeus, 1767

Aplysia parvula Guilding in Mörch, 1863

MATERIAL EXAMINED

Two specimens, 8 and $10 \mathrm{~mm}$ long, preserved (under rocks) (ZSM Mol 20130115), collector not recorded, September 2012.

\section{REMARKS}

This is the first record of Aplysia parvula from Ascension and the second record of an Aplysia species, after the record of A. dactylomela Rang, 1828 from the island by Rosewater (1975). Unfortunately, no photographs of living specimens of A. parvula were taken. Aplysia parvula is distributed in tropical to warm temperate waters worldwide, but preliminary molecular data point to the existence of a complex of species (V. Padula, unpublished data); this may represent a similar case to A. dactylomela, for which cryptic species were detected through molecular analysis (Alexander \& Valdés, 2013).

\author{
PANPULMONATA Jörger et al., 2010 \\ SACOGLOSSA Ihering, 1876 \\ Family CALIPHYLLIDAE Tiberi, 1881 \\ Genus Caliphylla A. Costa, 1867 \\ Caliphylla mediterranea A. Costa, 1867 \\ (Figure 3D)
}

\section{MATERIAL EXAMINED}

Two specimens, 4 and $5 \mathrm{~mm}$ long, preserved (on the alga Bryopsis plumosa , $8 \mathrm{~m}$ depth in English Bay, at night) (ZSM Mol 20130111), coll. P. Wirtz, 8 September 2012.

\section{REMARKS}

Originally described from the Mediterranean Sea, Caliphylla mediterranea was later recorded from different localities in the Caribbean Sea, Brazil and Senegal (Gascoine, 1979; Padula et al., 2012). It is here recorded from Ascension Island for the first time. It is unclear if the material of all these localities really belongs to the same species or represents a complex of cryptic species. Amphiatlantic distribution was supported for some, and rejected for other sacoglossan species in a recent study by Carmona et al. (2011).

\section{DISCUSSIDN}

The addition of seven new records, including two new species, almost doubles the number of 'opisthobranch' species known from Ascension Island (Rosewater, 1975). A list of all heterobranch sea slugs recorded from Ascension is given in Table 1. Due to Ascension's geographical position and isolation, a recurrent question is the origin of its shallow water fauna and flora and the degree of endemism (Price \& John, 1980). Among the 10 heterobranch species studied herein, four are considered circumglobal (M. undatus, D. dolabrifera, U. umbraculum and A. parvula) and one is recorded from the eastern Pacific and both sides of the Atlantic (P. areolatus). Such a range of distribution would not be naturally expected, as the maintenance of genetic structure between different oceans is highly incompatible to the biology of opisthobranch species with mostly benthic life (Goddard, 2004). Recent studies on sea slug species with similar wide geographical distribution revealed the existence of cryptic species. 'Navanax aenigmaticus', for example, is not distributed in the eastern Pacific, and on both sides of the Atlantic as previously thought, but indeed is a complex of three cryptic species, each restricted to one of these geographical regions (OrnelasGatdula et al., 2012). Hawaian specimens of 'Aplysia dactylomela' are not conspecific to Atlantic and Mediterranean ones (Alexander \& Valdés, 2013; Valdés et al., 2013). The existence of many more such cases is likely (Uribe et al., 2013). 
It is becoming clear that the traditional sea slug taxonomy, based on a reduced number of characters, does not allow secure delimitation of similar or even morphologically identical species (e.g. Krug et al., 2013), but additionally requires sound molecular approaches (see Jörger et al., 2012, Jörger \& Schrödl, 2013). For the circumglobal, widespread species considered in the present work, the identification provided here is tentative until comprehensive and integrative studies elucidate the real number of species involved and the correct names to be applied.

Briggs $(1974,1995)$ proposed that Ascension and St Helena together constitute a separate biogeographical province in the Atlantic. Data available on more studied groups, such as reef fish, which due to their life habits and biology can be compared to some benthic invertebrates, corroborate this idea (Bullock, 1980; Floeter et al., 2008). At the same time, it is known that Ascension and St Helena shallow water marine fauna receives strong influence from both the western and eastern Atlantic, including the occurrence of amphiatlantic species (Floeter et al., 2008). In general, the influence of the western Atlantic seems to be stronger (Manning \& Chace Jr, 1990), but see Floeter et al. (2008: p. 38). Briggs \& Bowen (2012) compiled biogeographical data and reported the openwater expanse of the mid-Atlantic, that is, the mass of water separating the western Atlantic and the eastern Atlantic, as a soft barrier for dispersion. The almost absent data on heterobranch sea slugs from the east coast of Africa limits the discussion in our case. From one side, the discovery of two new species (F. atlantica and P. mimica), unknown from elsewhere, reinforces the biogeographical province status of Ascension (Briggs, 1974, 1995, Floeter et al., 2008). On the other hand, the occurrence of the nudibranch Platydoris angustipes, currently only known from the tropical western Atlantic and from Ascension Island, corroborates the marine faunal affinity between these two regions.

\section{ACKNDWLEDGEMENTS}

P.W. is grateful to Paul Brickle and the Shallow Marine Surveys Group for the invitation to take part in the August-September 2012 expedition to Ascension Island, and to Kostas Tsiamis for drawing attention to the Caliphylla specimens for the identification of Bryopsis. Thanks to Stedson Stroud and Jolene Sim of the Ascension Conservation Department for their help during the expedition. We are grateful to the Shallow Marine Surveys Group and the South Atlantic Environmental Research Institute for organizing the expedition. We are very grateful to Ascension Island Government, the members of staff at the Conservation Centre and Ascension Island Dive Club for their cooperation, accommodation and hospitality. We are also grateful to British Forces South Atlantic Islands for their logistic support. We thank Simon Morley for the photograph of Diaulula sp. and Dolabrifera dolabrifera and Enrico Schwabe (ZSM) for assistance with the SEM and the management of specimens in the ZSM collection.

\section{FINANCIAL SUPPDRT}

The funding for this work came from a grant to the Shallow Marine Surveys Group from the Darwin Initiative (EIDCFo12). V.P. has a PhD grant from the CNPq-Brazil and DAAD-
Germany. Laboratory work is supported by DFG grants SCHR667/9,13 to M.S.

\section{REFERENCES}

Alexander J. and Valdés A. (2013) The ring doesn't mean a thing: molecular data suggests a new taxonomy for two Pacific species of sea hares (Mollusca, Opisthobranchia, Aplysiidae). Pacific Science 67, 283-294.

Alvim J. and Pimenta A. (2013) Taxonomic review of the family Discodorididae (Mollusca: Gastropoda: Nudibranchia) from Brazil, with descriptions of two new species. Zootaxa 3745, 152-198.

Bergh L.S.R. (1867) Phidiana lynceus og Ismaila monstrosa. Videnskabelige Meddeleser fra Danske Naturhistorisk Forening 7/9, 97-130.

Boettger C.R. (1955) Die Systematik der euthyneuren Schnecken. Zoologischer Anzeiger 18, 253-280.

Briggs J.C. (1974) Marine zoogeography. New York: McGraw-Hill.

Briggs J.C. (1995) Global biogeography. Developments in paleontology and stratigraphy 14. Amsterdam: Elsevier.

Briggs J.C. and Bowen B.W. (2012) A realignment of marine biogeographic provinces with particular reference to fish distributions. Journal of Biogeography 39, 12-30.

Camacho-García Y., Gosliner T.M. and Valdés A. (2005) Guía de Campo de las Babosas Marinas del Pacífico Este Tropical [Field Guide to the Sea Slugs of the Tropical Eastern Pacific]. San Francisco, CA: California Academy of Sciences, $130 \mathrm{pp}$.

Camacho-García Y., Pola M., Carmona L., Padula V., Villani G. and Cervera L. (2014) Diversity and distribution of the heterobranch sea slug fauna on the Caribbean of Costa Rica. Cahiers de Biologie Marine 55, 109-127.

Carmona L., Pola M., Gosliner T.M. and Cervera J.L. (2013) A tale that morphology fails to tell: a molecular phylogeny of Aeolidiidae (Aeolidida, Nudibranchia, Gastropoda). PLoS ONE 8, e6300o. doi: 10.1371/journal.pone.0063000.

Carmona L., Malaquias M.A.E., Gosliner T.M., Pola M. and Cervera J.L. (2011) Amphi-Atlantic distributions and cryptic species in sacoglossan sea slugs. Journal of Molluscan Studies 77, 401-412.

Cervera J.L., Calado G., Gavaia C., Malaquias M.A.E., Templado J., Ballesteros M., García-Gomez J.C. and Megina C. (2004) An annotated and updated checklist of the opisthobranchs (Mollusca: Gastropoda) from Spain and Portugal (including islands and archipelagos). Boletín del Instituto Español de Oceanografía 20, 1-122.

Debelius H. and Kuiter R.H. (2007) Nudibranchs of the world. Frankfurt: IKAN Unterwasserarchiv, $360 \mathrm{pp}$.

Domínguez M., García F.J. and Troncoso J.S. (2006) Some aspects of the family Chromodorididae (Opisthobranchia: Nudibranchia) from Brazil, with description of a new species. Scientia Marina 70, 621-634.

Edmunds M. (1975) An eolid nudibranch feeding on bryozoa. Veliger 17, 269-270.

Edmunds M. (1981) Opisthobranchiate Mollusca from Ghana: Chromodorididae. Zoological Journal of the Linnean Society 72, 175-201.

Floeter S.R., Rocha L.A., Robertson D.R., Joyeux J.C., Smith-Vaniz W.F., Wirtz P., Edwards A.J., Barreiros J.P., Ferreira C.E.L., Gasparini J.L., Brito A., Falcón J.M., Bowen B.W. and Bernardi G. (2008) Atlantic reef fish biogeography and evolution. Journal of Biogeography 35, 22-47.

Gascoigne T. (1979) A redescription of Caliphylla mediterranea Costa, 1867 (Opisthobranchia: Ascoglossa). Journal of Molluscan Studies $45,300-311$. 
García F.J., Troncoso J.S. and Domínguez M. (2002) New data on benthic opisthobranch molluscs from the archipelago of Fernando de Noronha (Brazil), with description of new species of Aegires Lóven, 1844. Iberus 20, 45-56.

García-Gómez J.C. (2002) Paradigmas de una fauna insólita. Los moluscos opistobranquios del Estrecho de Gibraltar, Serie Ciencias 20 Algeciras (Cádiz): Instituto de Estudios Gibraltareños, 397 pp.

Goddard J.H.R. (2004) Developmental mode in benthic opisthobranch molluscs from the northeast Pacific ocean: feeding in a sea of plenty. Canadian Journal of Zoology 82, 1954-1968.

Haszprunar G. (1985) The Heterobranchia-a new concept of the phylogeny of the higher Gastropoda. Zeitschrift für Zoologische Systematik und Evolutionsforschung 23, 15-37.

Johnson R.F. and Gosliner T.M. (2012) Traditional taxonomic grouping mask evolutionary history: A molecular phylogeny and new classification of the chromodorid nudibranchs. PLOS ONE 7, e33479. doi:10.1371/journal.pone.0033479.

Jörger K.M. and Schrödl M. (2013) How to describe a cryptic species? Practical challenges of molecular taxonomy. Frontiers in Zoology 10, 59.

Jörger K.M., Norenburg J.L., Wilson N.G. and Schrödl M. (2012) Barcoding against a paradox? Combined molecular species delineations reveal multiple cryptic lineages in elusive meiofaunal sea slugs. BMC Evolutionary Biology 12, 245.

Jörger K.M., Stöger I., Kano Y., Fukuda H., Knebelsberger T. and Schrödl M. (2010) On the origin of Acochlidia and other enigmatic euthyneuran gastropods and implications for the systematics of Heterobranchia. BMC Evolutionary Biology 10, 323.

Kocot K.M., Halanych K.M., and Krug P.J. (2013) Phylogenomics supports Panpulmonata: Opisthobranch paraphyly and key evolutionary steps in a major radiation of gastropod molluscs. Molecular Phylogenetics and Evolution 69, 764-71.

Krug P.J., Vendetti J.E., Rodriguez A.K., Retana J.N., Hirano Y.M. and Trowbridge C.D. (2013) Integrative species delimitation in photosynthetic sea slugs reveals twenty candidate species in three nominal taxa studied for drug discovery, plastid symbiosis or biological control. Molecular Phylogenetics and Evolution 69, 1101-1119.

Lubbock R. (1980) The shore fishes of Ascension Island. Journal of Fish Biology 17, 283-303.

Manning R.B. and Chace F.A. Jr. (1990) Decapod and stomatopod Crustacea from Ascension Island, South Atlantic Ocean. Smithsonian Contributions to Zoology. Washington, DC: Smithsonian Institution, No. 503.

Mörch O.A.L. (1863) Contributions à la faune malacologique des Antilles Danoises. Journal de Conchyliologie 11, 21-43.

Ornelas-Gatdula E., Camacho-García Y., Schrödl M., Padula V., Hooker Y., Gosliner T.M and Valdés A. (2012) Molecular systematics of the 'Navanax aenigmaticus' species complex (Mollusca, Opisthobranchia): coming full circle. Zoologica Scripta 41, 374-385.

Packer J.E. (1968) The Ascension handbook: a concise guide to Ascension Island, South Atlantic. Ascension Island Heritage Society, 68 pp.

Padula V. (2007) Caracterização taxonômica das espécies da subordem Aeolidina (Mollusca, Gastropoda, Nudibranchia) da Praia das Conchas, Cabo Frio, Rio de Janeiro, Brasil. Undergraduate thesis. Universidade Federal do Rio de Janeiro, Brazil.

Padula V., Bahia J., Vargas C. and Lindner A. (2011) Mollusca, Nudibranchia: new records and southward range extensions in Santa Catarina, Southern Brazil. Check List 7, 806-808.
Padula V., Bahia J., Correia M.D. and Sovierzoski H.H. (2012) New records of opisthobranchs (Mollusca: Gastropoda) from Alagoas, Northeastern Brazil. Marine Biodiversity Records 5, e57. doi: http:// dx.doi.org/10.1017/S1755267212000346.

Price H. and John D.M. (1980) Ascension Island, South Atlantic: a survey of inshore benthic macroorganisms, communities and interactions. Aquatic Botany 9, 251-278.

Rosewater J. (1975) An annotated list of the marine mollusks of Ascension Island, South Atlantic Ocean. Smithsonian Contributions to Zoology. Washington, DC: Smithsonian Institution, No.189.

Rudman W.B. (1980) Aeolid opisthobranch molluscs (Glaucidae) from the Indian Ocean and the south-west Pacific. Zoological Journal of the Linnean Society 68, 139-172.

Rudman W.B. (1999) Phidiana indica (Bergh, 1896). In Sea Slug Forum. Sydney: Australian Museum. Available at: http://www.seaslugforum. net/factsheet/phidindi (accessed in 8 April 2014)

Rudman W.B. (2000) Comment on Notaspids from Colombia by Phanor Montoya. Sea Slug Forum. Sydney: Australian Museum. Available at: http://www.seaslugforum.net/find/3211 (accessed in 8 April 2014).

Rudman W.B. (2003) Dolabrifera dolabrifera (Rang, 1828). Sea Slug Forum. Sydney: Australian Museum, Sydney. Available at: http:// www.seaslugforum.net/factsheet/doladola (accessed in 8 April 2014).

Smith E.A. (1890a) Report on the marine Molluscan fauna of the island of St Helena. Proceedings of the Zoological Society of London 1890, 247-317.

Smith E.A. (189ob) On the marine Mollusca of Ascension Island. Proceedings of the Zoological Society of London 1890, 317-322.

Uribe R.A., Nakamura K., Indacochea A., Pacheco A.S., Hooker Y. and Schrödl M. (2013) A review of the diversity and distribution of opisthobranch gastropods of the Peruvian coast, with the addition of three new records. Spixiana 36, 43-6o.

Valdés A, Hamann J., Behrens D.W. and Dupont A. (2006) Caribbean sea slugs: a field guide to the the opisthobranch mollusks from the tropical northwestern Atlantic. Silverdale, WA: Sea Challengers Natural History Books, 289 pp.

Váldes A., Alexander J., Crocetta F., Yokes M.B., Giacobbe S, Poursanidis D., Zenetos A., Cervera J.L., Caballer M. and Gali B.S. (2013) The origin and dispersal pathway of the spotted sea hare Aplysia dactylomela (Mollusca: Opisthobranchia) in the Mediterranean Sea. Aquatic Invasions 8, 427-436.

Wägele H., Klussmann-Kolb A., Verbeek E. and Schrödl M. (2014) Flashback and foreshadowing-a review of the taxon Opisthobranchia. Organisms Diversity and Evolution 14, 133-149.

and

Zenetos A., Gofas S., Russo G. And Templado J. (2003) CIESM atlas of exotic species in the Mediterranean: 3. Molluscs. Monaco: CIESM Publishers, $376 \mathrm{pp}$

\section{Correspondence should be addressed to:}

V. Padula

SNSB-Zoologische Staatssammlung München

Münchhausenstrasse 21, 81247, München

Germany and Department Biology II and GeoBio-Centre Ludwig-Maximilians-Universität München, Germany email: viniciuspadula@yahoo.com 